\title{
Ekwivalentverhoudings in tweetalige woordeboeke: Implikasies vir die databasis van 'n elektroniese tweetalige woordeboek van Suid-Afrikaanse Gebaretaal en Afrikaans*
}

Hanelle Fourie Blair, Buro van die WAT, Stellenbosch, Suid-Afrika en Departement Afrikaans en Nederlands, Universiteit Stellenbosch, Stellenbosch, Suid-Afrika(hfourie@sun.ac.za)

Opsomming: Hierdie artikel is 'n uittreksel uit 'n vollediger teoretiese raamwerk waarin 'n konsepmodel vir 'n elektroniese tweetalige grondslagfasewoordeboek van Suid-Afrikaanse Gebaretaal en Afrikaans voorgestel word, spesifiek vir die De la Bat Skool vir Dowes in Worcester, SuidAfrika (Fourie 2013). Die doel van die voorgestelde woordeboek is om die leerlinge van die De la Bat Skool elektroniese toegang tot geskrewe woordelyste te gee, met gebare en voorbeelde in gebaretaal wat in videoformaat vertoon word - dus in die vorm van 'n elektroniese woordeboek. ' $n$ Geskrewe woordelys voldoen glad nie in hierdie geval aan die behoeftes van skoolleerders nie en 'n woordeboek wat vir die Dowe teikengebruikers by die skool ontwerp is, sal van veel groter waarde wees in die leerders se omgang met gebaretaal sowel as die geskrewe taal. Sekere komponente van die model kan op die ou end ook deur gebruikers buiten die oorspronklike teikengebruikers toegepas word, sodat dit ook vir die breër Dowe gemeenskap van nut sou kon wees.

Hierdie artikel ondersoek die tipiese ekwivalentverhoudings in tweetalige woordeboeke en die kern van die artikel maak op grond daarvan voorstelle oor hoe die leksikograaf ekwivalentverhoudings tussen gebaretaal en Afrikaans in die voorgestelde woordeboek sou kon hanteer.

Sleutelwoorde: AFRIKAANS, DATABASIS, DOWE TEIKENGEBRUIKERS, EKWIVALENSIE, ELEKTRONIESE WOORDEBOEKE, GEBARETAAL, GEBARETAALWOORDEBOEKE, GLOSSERING, GRONDSLAGFASE, LEKSIKOGRAFIE, TWEETALIG, WOORDEBOEK

Abstract: Equivalent Relations in Bilingual Dictionaries: Implications for the Database of an Electronic Bilingual Dictionary of South African Sign Language and Afrikaans. This article is an extract from a more comprehensive theoretical framework in which a concept model for an electronic bilingual foundation phase dictionary of South African Sign Language and Afrikaans is suggested, specifically for the De la Bat School for

Hierdie artikel is ook aangebied as lesing by die Twintigste Jaarlikse Internasionale Konferensie van die African Association for Lexicography (AFRILEX), Universiteit van KwaZulu-Natal, Durban, Suid-Afrika, 6-8 Julie 2015. 
the Deaf in Worcester, South Africa (Fourie 2013). The purpose of the proposed dictionary is to give the learners of the De la Bat School electronic access to written school word lists, with signs and examples in sign language displayed in video format - therefore in the form of an electronic dictionary. A written word list does not meet the needs of school learners in this case and a dictionary that is designed for the Deaf target users at the school will be of far greater value in the learners' communication in both sign language and the written language. Certain components of the model can in fact also be implemented by users other than the original target users, so that it may also be of use to the broader Deaf community.

This article investigates the typical equivalent relations in bilingual dictionaries and on that basis the core of the article makes suggestions about how the lexicographer could treat equivalent relations between sign language and Afrikaans in the proposed dictionary.

Keywords: AFRIKAANS, BILINGUAL, DATABASE, DEAF TARGET USERS, DICTIONARY, ELECTRONIC DICTIONARIES, EQUIVALENCE, FOUNDATION PHASE, GLOSSING, LEXICOGRAPHY, SIGN LANGUAGE, SIGN LANGUAGE DICTIONARIES

\section{Inleiding}

Manley, Jacobsen en Pedersen (1988) is van mening dat beide eentalige en tweetalige woordeboeke eintlik 'n spul leuens is - eentalige woordeboeke begewe hulle op die weg om die indruk oor te dra dat woorde "betekenisse" het, eerder as sekere vermoëns om tot betekenisvolle kontekste toe te tree; tweetalige woordeboeke probeer weer aandui dat woorde "ekwivalente" in ander tale het, eerder as sekere verhoudings van gedeeltelike ekwivalensie wat verder gekompliseer word deur die reeks linguistiese en ekstralinguistiese kontekste waartoe die woorde en hul ekwivalente mag toetree (1988: 281). Die stelling is sekerlik ironies of komies bedoel, maar dui wel op die komplekse verhoudings tussen woorde en hul betekenis(se) in konteks in eentalige woordeboeke, en woorde en hul ekwivalente in konteks in tweetalige woordeboeke. Hierdie artikel ondersoek die tipiese ekwivalentverhoudings in tweetalige woordeboeke en die kern van die artikel maak op grond daarvan voorstelle oor hoe die leksikograaf ekwivalentverhoudings tussen gebaretaal en Afrikaans in die voorgestelde woordeboek sou kon hanteer. Daar is nie 'n brontaal of doeltaal per se in die voorgestelde woordeboek nie omdat die bewerkingseenhede parallel in albei tale gebied word, maar die ekwivalentverhoudings tussen die twee tale is steeds belangrik en sal veral 'n impak hê op hoe gebare en woorde in die databasis hanteer word.

\section{Ekwivalentverhoudings in tweetalige woordeboeke}

Die semantiese kommentaar in 'n ("gewone") tweetalige woordeboek moet ook voorsiening maak vir ' $n$ behandelingsprosedure wat al die polisemiese betekenisonderskeidinge in sy bestek het. Polisemie is ' $n$ taalspesifieke eienskap wat impliseer dat vir 'n polisemiese woord in die brontaal daar nie noodwendig ' $n$ 
vertaalekwivalent in die doeltaal gevind sal word wat presies dieselfde polisemiese betekenisonderskeidinge het nie (Gouws en Prinsloo 2005: 151, 152). Dit kom dus daarop neer dat die leksikograaf dikwels 'n aparte vertaalekwivalent vir elk van die polisemiese betekenisonderskeidinge van 'n lemma moet verskaf. Die versameling vertaalekwivalente, hetsy een of meer as een, wat in die semantiese kommentaar van 'n enkele artikel aangebied word, staan bekend as die vertaalekwivalentparadigma van die gegewe artikel. Die leksikograaf moet verseker dat die teikengebruiker van 'n bepaalde woordeboek inligting suksesvol uit ' $n$ vertaalekwivalentparadigma kan bekom. Die leksikograaf mag in die geval waar daar meer as een vertaalekwivalent in die paradigma verskyn, nie op die intuïsie van die gebruiker staatmaak om die korrekte keuse(s) te maak nie (Gouws en Prinsloo 2005: 152).

Gebruikers wat ' $n$ tweetalige woordeboek raadpleeg, verwag dikwels dat hierdie tipe woordeboek data oor die betekenis van die brontaalitem aanbied, soos wat deur die lemma verteenwoordig word, en sien die vertaalekwivalente as die "betekenis van die brontaalwoord in die ander taal". Hulle besef selde dat die data wat aangebied word, nie ' $n$ betekenisparafrase is nie maar eerder 'n lys vertaalekwivalente (Gouws en Prinsloo 2005: 153). Vertaalekwivalente mag egter nie gesien word as inskrywings wat die betekenis van die lemma gee nie, maar as leksikale items in die doeltaal wat gebruik mag word om die brontaalitem in 'n spesifieke situasie te vervang. Die leksikografiese behandeling in 'n tweetalige woordeboek mag dus nie vertaalekwivalente van hul tipiese kontekste en kotekste isoleer nie, soos die volgende voorbeeld uit die Groot Woordeboek (Kritzinger et al. 1972) toon:

vrug, (-te), fruit; result, effect; embryo, foetus ...

Vanuit 'n semantiese perspektief is dit verkeerd om te redeneer dat enige van die ekwivalente soos fruit, result, effect, embryo en foetus as die betekenis van die woord vrug gesien kan word; vrug beteken nie effect nie, maar kan in 'n spesifieke konteks met die woord effect vertaal word.

\section{Verskillende tipes ekwivalentverhoudings}

Leksikograwe het ' $n$ plig teenoor hul gebruikers om 'n aanbieding en behandeling van vertaalekwivalente te verseker wat ' $n$ ondubbelsinnige verkryging van inligting moontlik te maak uit die data wat in die semantiese kommentaar van 'n tweetalige woordeboek aangebied word. Die behoorlike aanbieding en behandeling van vertaalekwivalente voorvereis 'n deeglike begrip van die verskillende tipes ekwivalentverhoudings. Juis vanweë die feit dat so baie woordeboekartikels nie 'n een-tot-een-verhouding tussen die brontaal- en doeltaalitems toon nie, maak dit vir die leksikograaf noodsaaklik om addisionele inskrywings as ondersteunende materiaal aan te bied sodat die gebruiker ' $n$ ingeligte besluit kan maak wanneer 'n vertaalekwivalent vir 'n gegewe geval van die brontaalitem gekies word (Gouws en Prinsloo 2005: 154). 


\subsection{Volledige ekwivalensie}

Volledige ekwivalensie heers waar daar ' $n$ een-tot-een-verhouding bestaan tussen die brontaalitem, soos verteenwoordig deur die lemma, en doeltaalitem, soos verteenwoordig deur die vertaalekwivalent, op beide die leksikale en semantiese vlak. Hierdie tipe volledige ekwivalensie staan ook as kongruensie bekend: die brontaal- en doeltaalitems het presies dieselfde betekenis, funksioneer op dieselfde sintaktiese vlak en verteenwoordig dieselfde register, wat impliseer dat die doeltaalitem sonder enige beperkings as 'n vertaalekwivalent van die brontaalitem gebruik kan word (Gouws en Prinsloo 2005: 154):
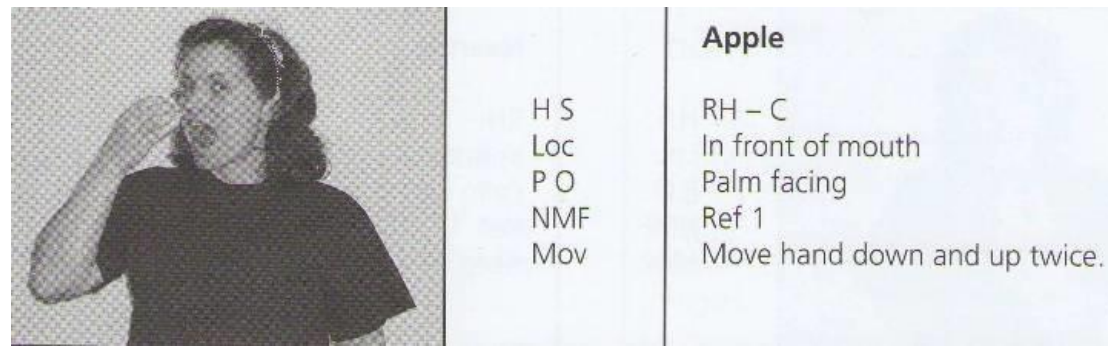

Figuur 1: Die gebaar APPEL, wat in kongruensie met die woord "appel" is (Howard 2008: 103)

Volledige ekwivalensie hoef nie noodwendig 'n een-tot-een-verhouding tussen bron- en doeltaal te verg nie, aangesien die doeltaal ook twee absolute sinonieme as ekwivalente vir ' $n$ gegewe brontaalitem kan hê. Dit is dan nie meer ' $n$ verhouding van kongruensie nie, maar eerder 'n subtipe divergensie (Gouws en Prinsloo 2005: 155), soos in die onderstaande bespreek sal word.

\subsection{Gedeeltelike ekwivalensie}

Gedeeltelike ekwivalensie heers waar daar nie 'n een-tot-een-verhouding tussen bron- en doeltaalitems bestaan nie. Dit kan op die leksikale vlak of die semantiese vlak of op albei leksikale en semantiese vlakke voorkom. Dit is ook van toepassing indien 'n een-tot-een-verhouding tussen die bron- en doeltaal slegs op leksikale vlak bestaan maar nie op semantiese vlak nie, soos wanneer 'n gegewe doeltaalitem die enigste vertaalekwivalent van die brontaalitem is maar die twee items nie presies dieselfde betekenis gemeen het nie. Die rede hiervoor kan wees dat die brontaalitem monosemies is waar die doeltaalitem polisemies mag wees en as 'n ekwivalent vir die brontaalitem funksioneer omdat een van sy betekenisonderskeidinge met die enigste betekenis van die brontaalitem oorvleuel (Gouws en Prinsloo 2005: 155).

' $n$ Tweede rede vir gedeeltelike ekwivalensie is wanneer 'n een-tot-eenverhouding op die leksikale vlak nie 'n parallelle ooreenkoms op die seman- 
tiese vlak het nie - die bron- en doeltaalitems het dus wel dieselfde betekenis maar val nie in dieselfde register nie, wat impliseer dat die doeltaalitem nie die brontaalitem in elke geval of situasie kan vervang nie aangesien dit vir 'n spesifieke register gemerk is (Gouws en Prinsloo 2005: 155, 156).

\subsubsection{Divergensie}

'n Een-tot-meer-as-een-verhouding tussen items in die bron- en doeltaal staan bekend as divergensie en impliseer nie noodwendig gedeeltelike ekwivalensie nie, maar kan ontstaan wanneer die doeltaal twee sinonieme as vertaalekwivalente vir die taalitem in die brontaal het. Hierdie een-tot-meer-as-een-verhouding kan 'n subkategorie van volledige ekwivalensie verteenwoordig, alhoewel die meerderheid van sulke gevalle 'n vorm van gedeeltelike ekwivalensie verteenwoordig (Gouws en Prinsloo 2005: 156). In 'n artikel wat 'n ekwivalente verhouding van divergensie vertoon, kan twee subtipes onderskei word, nl. leksikale divergensie en semantiese divergensie.

Leksikale divergensie heers wanneer 'n monosemiese leksikale brontaalitem wat as lemma funksioneer, een of meer vertaalekwivalente het wat gewoonlik gedeeltelike sinonieme in die doeltaal is en daarom 'n verhouding van gedeeltelike ekwivalensie toon. Indien die ekwivalente egter absolute of volkome sinonieme is, stel hulle 'n verhouding van volledige ekwivalensie daar. Leksikale divergensie word gewoonlik aangedui d.m.v. 'n komma as nietipografiese struktuurmerker wat gebruik word om hierdie ekwivalente te skei. Die voorbeeld grootliks uit die Groot Woordeboek (Kritzinger et al. 1972) is so 'n voorbeeld en het drie vertaalekwivalente:

groot'liks, greatly, to a great extent, to a high degree.

Die woorde greatly, to a great extent en to a high degree kan mekaar dus in enige vertaling van die woord grootliks vervang. Die meeste gevalle van leksikale divergensie toon ekwivalente wat gedeeltelike sinonieme is en die gebruiker behoort daarop attent gemaak te word dat alhoewel die gedeeltelike sinonieme die brontaalitem kan vervang, hulle dit nie in alle situasies kan doen nie. Die leksikograaf moet dus een of ander kontekstuele of kotekstuele leiding verskaf om die tipiese omgewing aan te dui waarin die gemeenskaplike semantiese waarde van die vertaalekwivalente geaktiveer word. Leksikale divergensie vereis nie noodwendig ' $n$ ingewikkelde sisteem om die beste toegang tot inligting te verseker nie, maar benodig wel die konsekwente toepassing van 'n weldeurdagte sisteem (Gouws en Prinsloo 2005: 156, 157).

Semantiese divergensie word beskou as die mees tipiese verskynsel van gedeeltelike ekwivalensie en heers waar die lemmateken 'n polisemiese leksikale item verteenwoordig. Polisemie is taalspesifiek en die kanse is daarom skraal dat 'n doeltaalitem dieselfde semantiese lading as die polisemiese brontaalitem sal hê. Die semantiese kommentaar bevat daarom 'n semantiese subkommentaar vir elk van die polisemiese betekenisonderskeidinge van die bron- 
taalvorm. Deur polisemiese betekenisonderskeidinge met 'n poliseemmerker soos 'n syfer aan te dui, vorm die poliseemmerkers deel van die kitstoegangstruktuur wat die gebruiker op sy soekroete na die gewenste inskrywing lei. Die gebruik van nommers as poliseemmerkers is 'n goed gevestigde en gestandaardiseerde leksikografiese gebruik wat in eentalige sowel as sommige tweetalige woordeboeke gebruik word. Gedrukte tweetalige woordeboeke maak ook dikwels gebruik van kommas en kommapunte as struktuurmerkers om 'n verhouding van semantiese divergensie aan te toon (Gouws en Prinsloo 2005: 157). In 'n elektroniese woordeboek, waar spasie nie dieselfde probleem as in 'n gedrukte woordeboek is nie, sou die gebruik van nommers eerder as kommas en kommapunte waarskynlik 'n beter en meer eksplisiete merker van semantiese divergensie wees. Soos wat in die bespreking hieronder in paragraaf 5 aangedui word, sou die grondslagfasewoordeboek kon kies om selfs polisemiese of homonimiese brontaalitems op 'n eenvoudige 'monosemiese' wyse per betekenisonderskeiding aan te bied, soortgelyk aan ander beginnerwoordeboeke, wat die gebruik van struktuurmerkers om semantiese divergensie aan te dui, in hierdie spesifieke geval oorbodig maak. Voorstelle oor die uitleg van die mikrostruktuur sal in in 'n volgende publikasie in meer besonderhede bespreek word.

\subsection{Nul-ekwivalensie}

Nul-ekwivalensie heers wanneer die doeltaal nie oor ' $n$ item beskik wat met ' $n$ lemma wat die brontaalitem verteenwoordig, gekoördineer kan word nie. Die afwesigheid van woorde in 'n vergelyking tussen twee tale staan as leksikale gapings bekend en is taalspesifiek. Dagut (1981) identifiseer twee soorte semantiese gapings in die oordrag van ' $n$ teks van een taal na 'n ander: gapings wat ontstaan vanweë taalkundige faktore en gapings wat ontstaan vanweë ekstralinguistiese faktore. Hierdie twee kategorieë staan onderskeidelik as linguistiese en referensiële gapings bekend (Gouws en Prinsloo 2005: 158, 159). 'n Linguistiese gaping kan geïdentifiseer word wanneer sprekers van beide die tale wat vergelyk word, bekend is met 'n sekere konsep maar waar die een taal nie 'n spesifieke woord het om daarna te verwys nie en die ander taal wel. Engelssprekende sowel as Afrikaanssprekende Suid-Afrikaners is byvoorbeeld vertroud met woorde en konsepte soos bakkie (beide die voertuig en 'n plastiekhouer waarin iets gebêre word), kloof, koeksister, kombi, bobotie, samoesa, ens. Hierdie woorde word algemeen in albei tale gebruik hoewel (of dalk juis omdat) Engels nie ' $n$ woord daarvoor het nie. 'n Referensiële gaping ontstaan wanneer die sprekers van taal B glad nie vertroud is met ' $n$ referent of konsep wat in taal A 'n naam het nie, bv. sprekers van 'n Europese taal wat nie weet wat die woord lobola beteken nie, al is dit welbekend aan al die sprekers van die Ngunitale. Die brontaalitem verteenwoordig dus 'n referensiële gaping aangesien dit 'n kultuurgebonde leksikale item is en die sprekers van die doeltaal nie daardie kultuur deel nie (Gouws en Prinsloo 2005: 159). Die gebrek aan vertaalekwivalente waar leksikale gapings bestaan, skep 'n verhouding van nul-ekwivalen- 
sie en lei dikwels tot die gebruik van surrogaatekwivalente, m.a.w. 'n doeltaalinskrywing wat 'n vertaalekwivalent vervang. Die aard van die leksikale gaping in die doeltaal sal ook die omvang bepaal van die leiding wat die leksikograaf in die behandeling van die doeltaalitem gee: in die geval van 'n linguistiese gaping weet die leksikograaf dat die sprekers van die doeltaal ook bekend is met die spesifieke konsep in die brontaal en 'n kort beskrywing of omskrywing van betekenis sal voldoende wees; in die geval van 'n referensiële gaping is 'n meer omvattende behandeling nodig aangesien die gebruikers van die doeltaal nie bekend is met die konsep wat deur die brontaallemma voorgestel word nie (Gouws en Prinsloo 2005: 159, 160). Artikels waarin nul-ekwivalensie heers, is die ideale kandidate vir die insluiting van prentjies of illustrasies in woordeboeke wat van prentjies/illustrasies in die mikrostruktuur gebruik maak - 'n prentjie sê immers meer as 'n duisend woorde.

\subsection{Konvergensie, of omgekeerde ekwivalensie}

Konvergensie ontstaan wanneer die konsep wat onderliggend aan die een taal (as doeltaal) se uitdrukking of lemma is, dus minder onderskeidende eienskappe het as dié wat onderliggend aan die ander taal (as brontaal) se lemmas is. Daar ontstaan gevolglik konvergensie van die brontaal na die doeltaal wanneer 'n enkele doeltaalitem ooreenkom met die som van die betekenis van twee (of meer) brontaalitems (Svensén 2009: 259):

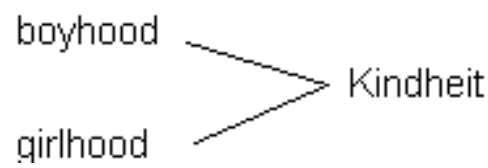

Figuur 2: Konvergensie van die brontaal na die doeltaal (Svensén 2009: 259)

\subsection{Kommunikatiewe ekwivalensie}

Die funksie(s) van 'n spesifieke woordeboek, bv. 'n teksresepsie- of 'n teksproduksiefunksie, behoort 'n invloed te hê op die aard en omvang van die addisionele inskrywings wat gegee word om die vertaalekwivalente te ondersteun en aan te vul. Die meerderheid tweetalige woordeboeke word as bifunksionele produkte saamgestel en moet dus hul gebruikers in minstens die funksies van teksresepsie of -produksie ondersteun. Tog gee die data wat in die semantiese kommentaar van tweetalige woordeboeke aangebied word, dikwels die gebruiker min geleentheid om die regte ekwivalent te kies - leksikograwe beperk te dikwels hul pogings tot die blote lysting van 'n aantal doeltaalitems om vertaalekwivalensie te verseker. In sulke gevalle ontvang die gebruikers geen leiding om hulle in die keuse van ekwivalente by te staan of om hulle te help om die doeltaalitems op die regte manier te gebruik nie. Dit kan voldoende wees in gevalle van teksresepsie, maar nie vir teksproduksie nie - kommunikatiewe 
ekwivalensie kan slegs bereik word indien die behandeling van die vertaalekwivalentparadigma nie net tot 'n lysting van ekwivalente beperk word nie, maar as hierdie ekwivalente deur konteks- en koteksinskrywings aangevul word wat die gebruiker kan help om die korrekte ekwivalent vir 'n gegewe geval van die brontaalitem te kies en om hierdie ekwivalent op die regte manier te gebruik (Gouws en Prinsloo 2005: 161, 162). Voorbeelde van vertaalekwivalente wat sonder konteks- of koteksinskrywings gelys word en die gebruiker dus nie met teksproduksie kan bystaan nie, lyk soos volg:

form ... vorm; maak; fatsoeneer; formeer; set; kweek; oprig, stig; in gelid stel, rangskik ... (Tweetalige Woordeboek) (Bosman et al. 1984)

op'staan, (-ge-), stand up, rise, arise, get up; get on one's legs; rebel, revolt ... (Groot Woordeboek) (Kritzinger et al. 1972)

Beide hierdie artikels toon polidivergensie en het dus 'n kombinasie van leksikale en semantiese divergensie. Semantiese ekwivalensie is wel tussen die lemmas en hul onderskeidelike vertaalekwivalentparadigmas vasgestel, maar nie kommunikatiewe ekwivalensie nie (Gouws en Prinsloo 2005: 162). 'n Oplossing vir hierdie probleem is te vinde in die voorsiening van bykomende inskrywings sodat ruimte geskep word vir nielemmatiese adressering met die vertaalekwivalente as adresse van die konteks- en koteksinskrywings, soos in die volgende paragraaf bespreek word.

Die bostaande voorbeelde maak slegs voorsiening vir lemmatiese adressering, alhoewel die adresseringstruktuur van tweetalige woordeboeke vir beide lemmatiese en nielemmatiese adressering voorsiening kan maak. Nielemmatiese adressering kan die prosedures van lemmatiese adressering aanvul en die leksikograaf in staat stel om die gebruiker met teksproduksie te help. Nielemmatiese adressering impliseer dat die lemma nie die enigste behandelingseenheid in 'n woordeboekartikel behoort te wees nie maar dat die status van vertaalekwivalente as doeltaalitems verhoog moet word om ook behandelingseenhede te wees. Addisionele inskrywings kan dus by die vertaalekwivalente gevoeg word om die gebruiker te help om hulle beter te verstaan en om ' $n$ idee te vorm van watter ekwivalent die brontaalitem in 'n spesifieke geval kan vervang (Gouws en Prinsloo 2005: 162). 'n Voorbeeld van nielemmatiese adressering wat kommunikatiewe ekwivalensie help bereik, kan in die volgende voorbeeld uit die Tweetalige Aanleerderswoordeboek (Du Plessis 1993) gesien word:

figure 1 figuur [a] Sy het ' $n$ mooi figuur en lieflike lang bene. She has a beautiful figure and lovely long legs. [b] Die skoolhoof is ' $n$ belangrike figuur op ' $n$ klein dorpie. The headmaster is an important figure in a small village. 2 syfer " $E k$ kan nie dié syfer uitmaak nie. Is dit ' $n 1$ of ' $n$ 7?" "I can't make out this figure. Is it a 1 or a $7 ? " . .$.

In hierdie behandeling van die polisemiese Engelse woord figure is die verskillende semantiese subkommentare met nommers as struktuurmerkers gemerk, 
wat uitdruklik aandui dat die lemma 'n polisemiese leksikale item verteenwoordig. Die geïntegreerde mikrostruktuur laat elke vertaalekwivalent toe om dadelik deur 'n beskrywende voorbeeld gevolg te word wat aan hierdie vertaalekwivalent geadresseer is, en dui dus aan hoe die doeltaalitem gebruik word om die spesifieke polisemiese betekenisonderskeiding van die lemma as brontaalitem uit te druk (Gouws en Prinsloo 2005: 162). Konteksinskrywings kan ook in die toepassing van nielemmatiese adresseringsprosedures gebruik word om kommunikatiewe ekwivalensie te bevorder. In die meeste gedrukte woordeboeke word van woorde tussen hakies as konteksinskrywings gebruik gemaak, soos in die volgende voorbeeld uit die Oxford French Dictionary and Grammar (OFD) (Rowlinson 2001) gesien kan word:

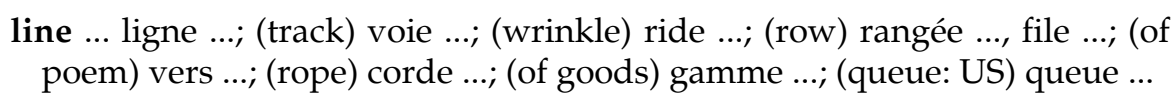

\section{Glosse en ekwivalensie in gebaretaalwoordeboeke}

Gebaretale word tipies gebaar-vir-gebaar in die geskrewe taal getranskribeer d.m.v. 'n geskrewe glos wat in hoofletters geskryf word. Prosodie word dikwels in boskrif geglos met die omvang daarvan tussen hakies aangedui:

$$
\begin{aligned}
& \text { [I LIKE] NEGATIVE }[\text { WHAT?] RHETORICAL, GARLIC. } \\
& \text { "I don't like garlic." }
\end{aligned}
$$

Figuur 3: Voorbeeld van die glossering van 'n gebare-uiting d.m.v. geskrewe woorde en prosodiese inligting in boskrif gevolg deur 'n vertaling van die uiting in idiomatiese Engels (Wikipedia 2012)

Primêre glosse word gewoonlik beskou as die naaste vertaalekwivalente uit die geskrewe taal vir 'n spesifieke gebaar, terwyl sekondêre glosse beskou word as enige ander betekenisse wat aan die gebaar toegeken sou kon word in die geval van enkele of minimale veranderinge aan die gebaar, soos 'n verandering in handpalmoriëntasie of beweging:

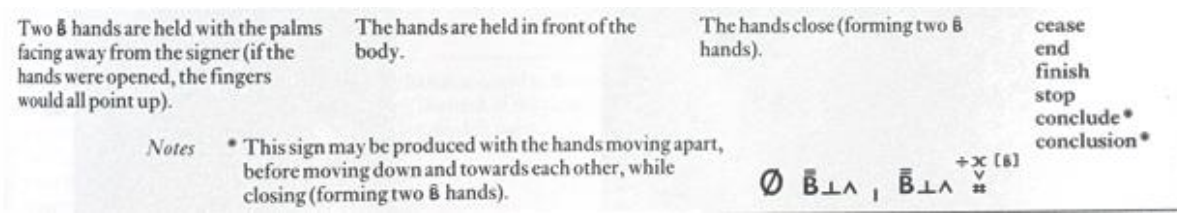

Figuur 4: Voorbeeld van die gebruik van sekondêre glossering in die geval waar ' $n$ verandering in die beweging van die gebaar 'n sekondêre betekenis kan meebring (Brien 1992: 749) 
In die tradisie van gebaretaalnavorsing word die woord glos gebruik om na die transkripsie van die betekenis van 'n gebaar te verwys (lekewoordeboekmakers maak ook dikwels van hierdie term gebruik, waarskynlik uit onkunde, maar dit is nie nou hier ter sprake nie). Leksikograwe van gesproke/geskrewe tale vind dié gebruik egter vreemd en verkies om van ' $n$ vertaalekwivalent te praat. Dit is egter belangrik om te onthou dat gebaretale nie sonder meer met gesproke tale vergelyk kan word nie, al betwis niemand die feit dat gebaretale nié om daardie of enige ander rede minderwaardige tale is nie. Hulle is eerder unieke tale wat in sekere opsigte op unieke maniere funksioneer. Om 'n gebaretaal in terme van 'n gesproke taal te beskryf, is in baie opsigte problematies, aangesien dit maklik is om sekere kenmerke of beperkinge van die gesproke taal (in vergelyking met die gebaretaal) op die gebaretaal te projekteer. Geen gebaretaalleksikograaf het ' $n$ maklike taak wanneer besluite geneem moet word t.o.v. leksikalisering, aanhalingsvorme en selfs woordsoorte nie, omdat (i) daar nie ' $n$ bepaalde tradisie of voorskrif hiervoor ( $k a n$ ) bestaan nie (ii) aangesien gebaretale hulle nie summier in dieselfde kassies as gesproke tale laat groepeer nie - gebaretale "is prone to synthesising localised meanings that are not strictly lexicalised" (McKee en McKee 2012). Wanneer 'n gebaretaal met 'n gesproke/geskrewe taal in ' $n$ tweetalige woordeboek vergelyk of gekontrasteer word, gebeur dit baie selde dat 'n enkele gebaar-tot-woord-ekwivalent in die geskrewe taal gevind kan word. Dit is selfs gevaarlik en misleidend om die indruk te skep dat so 'n gebaar-tot-woord- of woord-tot-gebaar-verhouding sonder meer bestaan. Feitlik alle gebaretaalwoordeboeke het te make met hierdie unieke sintetiserende eienskap van gebaretale en die enigste algemene hantering hiervan is om die moontlike betekenisse van 'n gebaar d.m.v. glosse aan te dui. Neem die onderstaande voorbeeld uit die Dictionary of British Sign Language/English (Brien 1992: 456-7):

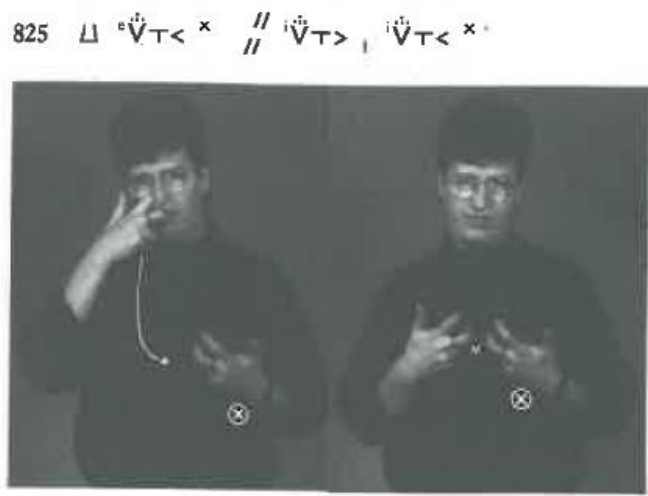

Figuur 5: Brien 1992: 456 
'n Uittreksel uit die woordeboekartikel vir dié gebaar lyk soos volg:

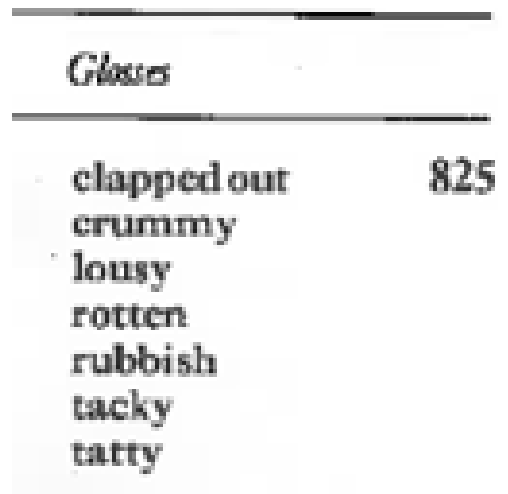

Figuur 6: Brien 1992: 457

Onder die opskrif "Glosses" word 'n lys van die gebaar se moontlike "vertaalekwivalente" as glosse aangedui, nl. "clapped out", "crummy", "lousy", "rotten", "rubbish", "tacky" en "tatty". In die gebruiksaanwysings van hierdie woordeboek word die volgende oor die glosse gesê: "the glosses column contains a number of entries that can be thought of as possible parallels to the sign given opposite" (xv) (eie beklemtoning). Dit is duidelik dat die woordeboek nie probeer om aan te voer dat die inskrywings in die glossekolom die vertaalekwivalente van die betrokke gebaar is nie, maar dat hulle "moontlike parallelle" is in 'n taal waar die lyne van grammatiese sinsontleding en beskrywing soms 'n bietjie wasig is in vergelyking met dié van gesproke/ geskrewe tale.

\section{Die impak van ekwivalentverhoudings op die databasis en voorstelle vir die woordeboek}

Die ekwivalentverhoudings tussen gebaretaal en Afrikaans het sekere implikasies vir die manier(e) waarop gebare en woorde in die databasis hanteer sal word. Beide gebare asook geskrewe woorde is parallelle lemmakandidate wat lede van die databasis is en daarin bewerk word.

Die voorgestelde woordeboek is gebaseer op een elektroniese databasis van gebare én geskrewe woorde wat d.m.v. 'n elektroniese soekprosedure (waarskynlik via 'n webblaaier) toegang tot 'n gebaar parallel aan 'n geskrewe woord sal verleen sodat beide gebare én geskrewe woorde soekbaar is en die woordeboek volledig tweetalig is. 


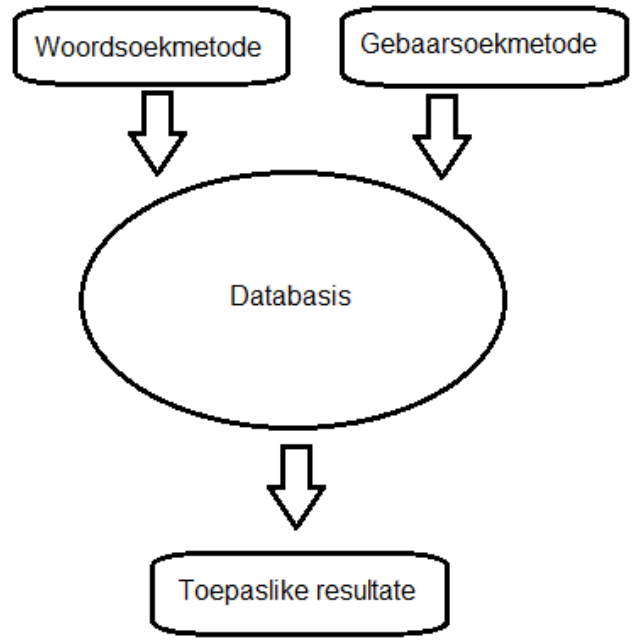

Figuur 7: Beide die woordsoekmetode en die gebaarsoekmetode lei tot toepaslike resultate

'n Databasis van gebare word saamgestel wat bestaan uit (a) gebare waarvoor die woorde in die geskrewe klaswoordelyste vertaalekwivalente sou wees, en (b) enige bykomende gebare wat deur ' $n$ raadgewende Dowe gebaretaalkomitee gekies of aanbeveel word tydens die uiteindelike praktiese samestelling van die voorgestelde woordeboek. Gebare en woorde word dus per betekeniswaarde gedupliseer en onderling as gidselemente aan mekaar gekoppel.

Die woorde wat in die voorgestelde woordeboek as geskrewe lemmas aangebied word, behoort ooreen te stem met die doeltaalvlak van die gebruiker en sal dus nie noodwendig alle moontlike glosse van die gebaar (sien paragraaf 4) as lemmas in die geskrewe taal insluit nie.

'n Soekopdrag gaan nie noodwendig dadelik die volle mikrostrukturele bewerking van ' $n$ bepaalde meervoudige lemma oplewer nie maar slegs ' $n$ deel van die mikro- en artikelstruktuur. Die data wat in hierdie deelstruktuur gebruik word, kan meebring dat dit in sommige gevalle selfs nie vir die gebruiker nodig sal wees om die soekproses voort te sit deur op een van die soekresultate te klik nie, amper soos wanneer die gebruiker van 'n gedrukte woordeboek 'n artikel vinnig opsoek net om die vorm of spelling te kontroleer en nie enige behoefte daaraan het om verdere inligting aan die artikel te onttrek nie. Hipotetiese voorbeelde van so 'n deelstruktuur word hieronder in figuur 12 en 13 voorgestel. Die vollediger mikrostrukturele bewerking van die lemma - of, meer spesifiek, 'n spesifieke betekeniswaarde van die lemma - word bekom deur een van die soekresultate te selekteer.

Vanweë die parallelle aanbieding van albei tale en die meervoudige lemmas wat daaruit spruit, kan die verhouding tussen die twee tale ook nie in terme van gewone ekwivalentverhoudings in tweetalige woordeboeke bespreek 
word nie. Dit sal wel in terme van een-tot-een-, een-tot-meer- en een-tot-nulverhoudings bespreek en geillustreer word.

\subsection{Een gebaar tot een woord, en omgekeerd}
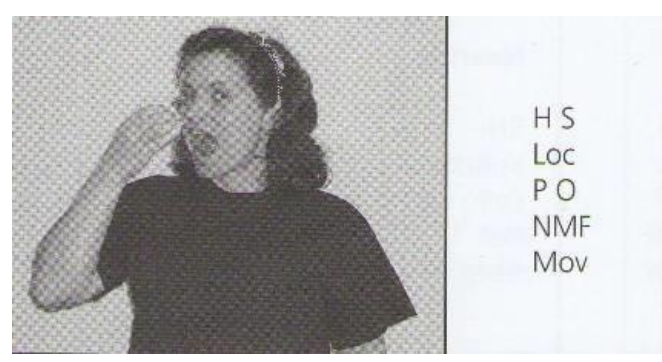

Apple

$\mathrm{RH}-\mathrm{C}$

In front of mouth

Palm facing

Ref 1

Move hand down and up twice.

Figuur 8: Die gebaar APPEL, wat in kongruensie met die woord "appel" is (Howard 2008: 103)

In gevalle van 'n een-tot-een-verhouding tussen die twee tale word geïmpliseer dat daar dus net een geskrewe woord aan 'n gebaar (en omgekeerd) in die databasis toegeken of gekoppel sal word en hierdie gevalle behoort geen probleme te veroorsaak nie.

\subsection{Een gebaar tot meer as een (sinonieme) Afrikaanse woord}

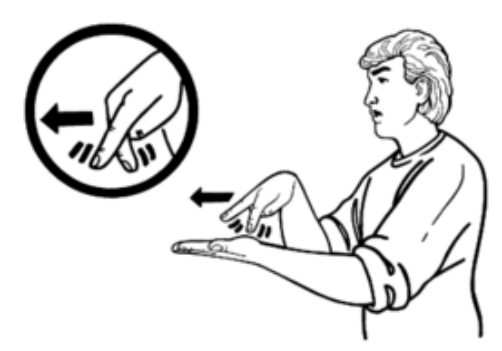

Figuur 9: Die gebaar LOOP/STAP wat, soos uit die glossering afgelei kan word, met die sinonieme loop of stap vertaal kan word

In die geval van 'n een-tot-meer-verhouding van gebaretaal na Afrikaans, soos in die geval van die gebaar wat met die Afrikaanse sinonieme "loop" en "stap" vertaal kan word, sal beide woorde in die databasis aan dieselfde gebaar toegeken of as gidselemente vir dieselfde gebaar opgeneem moet word sodat ' $n$ soektog na enige van die twee woorde 'n suksesvolle en toepaslike soekresultaat lewer: 


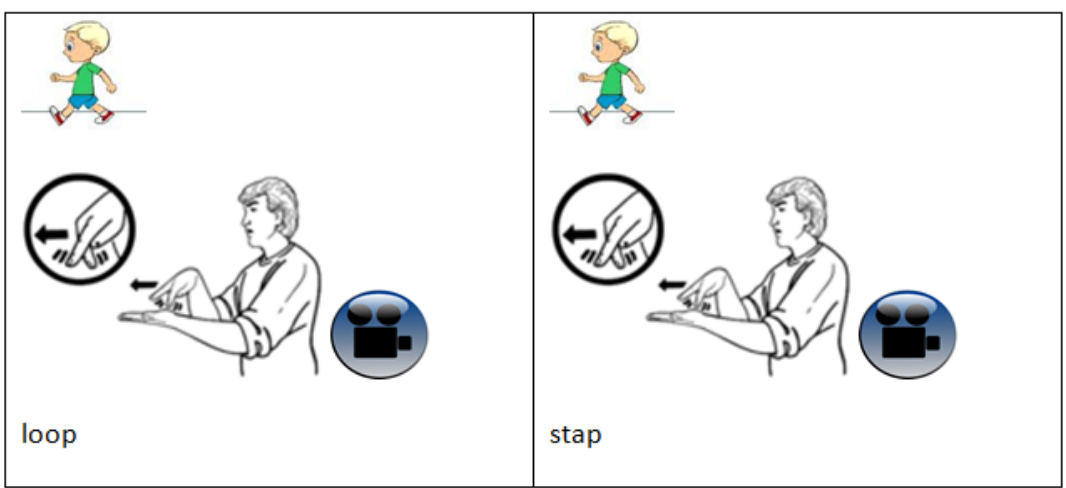

Figuur 10: Hipotetiese soekresultaat vir 'n gebaar wat in 'n een-tot-meer-verhouding met die geskrewe taal staan

Let wel: in figuur 10 word die geskrewe woorde nie in hoofletters gegee soos wat gewoonlik in die glossering van gebare gedoen word nie, aangesien die geskrewe woorde nie meer as vertaalekwivalente of glosse beskou word nie maar as lemmas. Die gebruik van 'n meervoudige lemma word in 'n komende publikasie bespreek.

\section{3 gebaar tot meer as een woord}

'n Voorbeeld van 'n polisemiese gebaar wat voorkom in die spesifieke dialek of variant van SASL wat by De la Bat gebruik word, is die gebaar wat "lemoen" of "oranje" kan beteken (homonieme of poliseme is egter baie skaars in gebaretaal en hierdie voorbeeld is die enigste een wat by navraag gevind kon word). Hierdie gebaar is besonder gepas in hierdie bespreking aangesien dit geskrewe woorde verteenwoordig wat in die grondslagfasewoordelys verskyn en wat dus ook gelemmatiseer sal word:

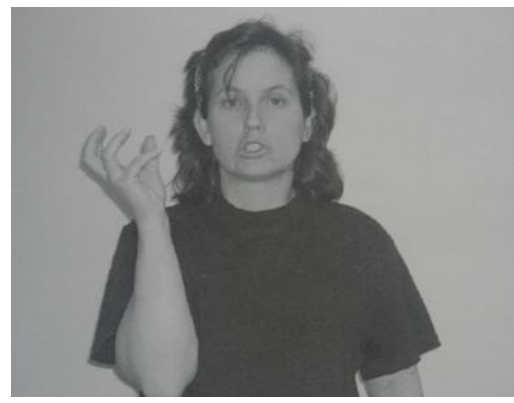

Figuur 11: Die polisemiese gebaar wat "oranje" of "lemoen" kan beteken, soos dit by De la Bat gebruik word (Howard 2008: 104) 
Die deelstruktuur van die soekresultaat wat deur die gebaarsoekmetode bekom word, sou soos in figuur 12 aangedui word.

Die teikengebruiker van die Longman Grondslagfasewoordeboek (Gouws et al. 2010) wat die woord "lig" in die alfabetiese lys opsoek (Gouws et al. 2010: 55, 56) en sien dat daar drie lemmas vir daardie woord aangebied word, nl. 'n selfstandige naamwoord, ' $n$ byvoeglike naamwoord (teenoor donker) en nog ' $n$ byvoeglike naamwoord (teenoor swaar), beskik nie oor die insig dat die woord twee maal homonimies en ook twee maal polisemies is nie - dit word ook nie van die gebruiker verwag nie. Die betekeniswaardes vir "lig" word dus nie soos in algemene tweetalige woordeboeke van getalle in boskrif voorsien om homonieme te onderskei nie, en ook nie van Romeinse syfers om polisemiese betekenisonderskeidings te onderskei nie, maar eerder in 'n heeltemal streng alfabetiese makrostruktuur, sodat elkeen as 'n aparte lemma in die makrostruktuur verskyn.

Die gebare en woorde wat in die databasis is en wat polisemies of homonimies is, sal dus op 'n soortgelyke wyse vir die grondslagfasewoordeboek 'gedupliseer' kon word sodat elke betekeniswaarde apart in die soekresultate van onderskeidelik die gebaarsoekmetode en woordsoekmetode aangebied word trouens, ' $n$ volkome tweetalige woordeboek waarin sowel gebaretaal as 'n geskrewe taal as bron- óf doeltaal kan optree, vereis hierdie tipe bewerking. Die soekresultaat vir een gebaar waaraan meer as een woord met verskillende betekeniswaardes toegeken word, sou dus soos in figuur 12 kon lyk (steeds met prentjies as aanduiders om die onderskeid so duidelik moontlik te maak sodat die gebruiker deur visuele leidrade waarvan die betekenis deursigtig is, gelei word):

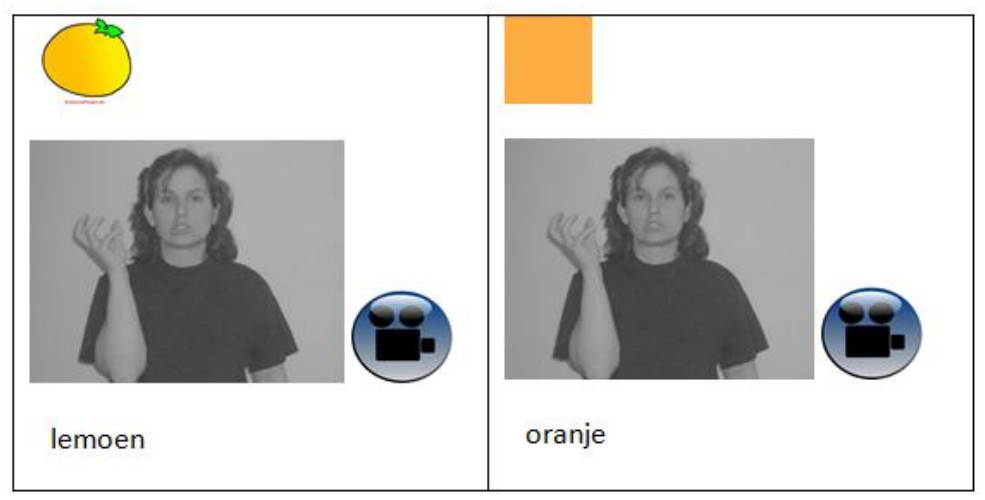

Figuur 12: Hipotetiese soekresultaat vir 'n gebaar waaraan meer as een woord met verskillende betekeniswaardes in die databasis toegeken word en wat, deur die gebaarsoekmetode te gebruik, as aparte soekresultate vertoon

Die herhaling of duplisering van gebare én woorde per betekeniswaarde in die databasis sou ook verseker dat die tematiese soekmetode (waar gebare volgens 
referent en dus in een spesifieke betekeniswaarde vertoon word) sowel as die woord- en gebaresoekmetodes gepaste resultate lewer. Dit sou verhoed dat die tematiese kategorieë uit ' $n$ aparte databasis moet bestaan en laat die tematiese soekmetode op ' $n$ uniforme en bevredigende manier met die woord- en gebaresoekmetodes sluit.

\subsection{Een woord tot meer as een gebaar}

In gevalle van een woord waaraan meer as een gebaar toegeken word, sal dit waarskynlik in die meerderheid gevalle wees a.g.v. een woord met meer as een betekeniswaarde, tensy daar natuurlik hoegenaamd gevalle van sinonieme gebare (waarvan geen voorbeelde gevind kon word nie) of variante van 'n gebaar teëgekom word. In die geval van variante sou die meer of mees gebruiklike variant wat op 'n proskriptiewe wyse deur die woordeboek aanbeveel kon word, met 'n etiket gemerk moet word om die voorgestelde keuse aan te dui. Gegewe die beperkte woordeskat wat in die woordeboek op leerders in die grondslagfase gerig sal word, is dit redelik onwaarskynlik dat daar enige gevalle van variasie sal voorkom. Dit sal waarskynlik eers in woordeboeke vir meer gevorderde leerders in die intermediêre en senior fases na vore kom en kan dan op die spesifieke gebruikersvlak hanteer word.

'n Soektog na die polisemiese of homoniese woord sal dus al die gebare wat daardie woord kan "vertaal", oplewer. Die deelstruktuur wat in die soekresultate gereflekteer word, is van die uiterste belang om die gebruiker te help om die regte keuse te maak deur te verseker dat genoeg kontekstuele leiding verskaf word. Die deelstruktuur van sulke soekresultate sou soos volg kon lyk, bv. in die geval van die geskrewe woord "lig" wat beide homonimies en polisemies is:

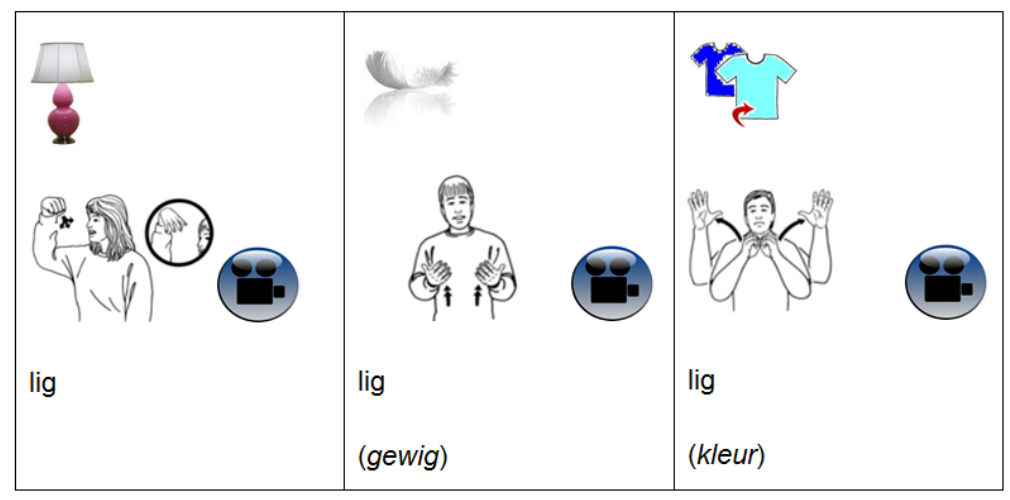

Figuur 13: Hipotetiese soekresultaat van die woord "lig"

Die uitleg t.o.v. die gebare en geskrewe woorde in figuur 13 is slegs hipoteties en is ter wille van bladsyruimte met die gebaar bo en die geskrewe woord 
daaronder gedoen - daar is geen rede hoekom die gebaar en die geskrewe woord as parallelle lemmas in 'n volledig tweetalige woordeboek nie langs mekaar geplaas kan word nie. Die feit dat gebare en woorde per betekeniswaarde in die databasis gemerk word, lei tot meervoudige lemmas en die mikrostruktuur behoort ook aan te dui dat daar nie voorkeur aan die een bo die ander gegee word nie.

Soos gesien kan word in figuur 13, sou die deelstruktuur van die soekresultate ook van aanduiders (die prentjies) gebruik kon maak om die referent waarna verwys word, te beklemtoon en te illustreer. Dit sal die gebruiker help om die korrekte lemma te kies en kommunikatiewe ekwivalensie ondersteun.

Soos reeds genoem, bied die deelstruktuur nie net leiding aan die gebruiker in die korrekte keuse van 'n lemma (of die betekeniswaarde van ' $\mathrm{n}$ lemma) nie, maar kan dit reeds aan sommige basiese navrae van die gebruiker voldoen, amper soos wanneer die gebruiker van 'n gedrukte woordeboek 'n artikel net vlugtig besoek om die vorm of spelling na te gaan. Watter datatipes ook al as inskrywings vir die deelstruktuur van soekresultate gekies word, behoort só gekies te word dat dit die gebruiker se basiese navrae reeds op hierdie vlak kan beantwoord.

\subsection{Een-tot-nul-verhoudings}

Daar is nie (baie) inligting beskikbaar oor een-tot-nul-verhoudings van SASL na Afrikaans nie, waarskynlik omdat 'n gebaretaal nog nooit (in Suid-Afrika en slegs selde elders) as brontaal in 'n woordeboek aangebied is nie maar meer dikwels as doeltaal. Daar is dus heelwat meer gerapporteerde gevalle van eentot-nul-verhoudings van Afrikaans na SASL, en gebruikers kla dikwels dat daar nie ' $n$ gebaar is wat ' $n$ spesifieke konsep of term in Afrikaans kan vertaal nie. Sulke gevalle kom veral in gespesialiseerde woordeskat voor, soos wetenskap, landbou, en dergelike. Daar is selfs binne die Dowe gemeenskap nie ooreenstemming oor die verhouding van een-tot-nul-verhoudings van Afrikaans na SASL nie: sommige Dowes sal aandui dat daar 'n linguistiese gaping bestaan, terwyl ander sal sê dat dit glad nie waar is nie en dat die gebaar eenvoudig nie baie bekend is nie, waarskynlik juis omdat dit tot 'n gespesialiseerde veld van die woordeskat behoort. Aangesien SASL nie geskryf kan word nie, is dit dikwels moeilik om woordeskat (of 'gebareskat') wat dalk in een deel van die land ontwikkel (word) na ander dele van die land te laat versprei. Daar bestaan vermoedelik min of geen gevalle van referensiële gapings tussen SASL en Afrikaans nie, aangesien daar nie dieselfde tipe kultuurverskille ter sprake is wat dikwels tussen die sprekers van ander taalpare voorkom nie Dowes leef steeds 'binne' die kultuur van die mense rondom hulle. Die mees ooglopende verskille is kultuurspesifieke dinge wat tot die Dowe kultuur behoort, soos ' $n$ deurklokkie wat uit 'n flikkerende lig in die Dowe persoon se huis bestaan eerder as 'n apparaat wat 'n geluid maak soos in die huis van ' $n$ horende persoon. Hierdie referente sou in 'n tematiese kategorie saamgegroe- 
peer kon word om die horende gebruiker 'n oorsig van al dié tipe items te gee sonder om individueel daarvoor te gaan soek, veral in gevalle waar die horende gebruiker dalk nie eens daarvan bewus is dat daar sulke verskille bestaan nie. Die gebare vir sulke referente in die Dowe kultuur sou dan ook met die naaste woord in die horende kultuur "vertaal" of daaraan gekoppel kon word, bv. in die geval van 'n gebaar soos LIG FLIKKER wat dui op die visuele sein wat aan 'n Dowe persoon wys dat daar iemand by die deur is, sou die woord "deurklokkie" ook in die databasis aan die gebaar gekoppel kon word sodat 'n woordsoektog na "deurklokkie" ook hierdie gebaar as soekresultaat sal lewer. 'n Skakel tussen sulke artikels en 'n tematiese kategorie van al die toepaslike items uit die Dowe kultuur, of 'n buiteteks oor Dowe kultuur, sou die gebruiker dan kon lei na 'n vollediger oorsig van kultuurspesifieke items.

\section{Algemene slotopmerkings}

Hierdie artikel het die ekwivalentverhoudings tussen gebaretaal en Afrikaans ondersoek en aangedui watter impak hierdie verhoudings op die hantering van die gebare en woorde in die databasis sou hê. Al het die voorgestelde woordeboek nie 'n spesifieke bron- of doeltaal nie, maar eerder twee tale wat parallel aan mekaar aangebied word, sal die voorgestelde hantering van die ekwivalentverhoudings tussen woorde en gebare in die databasis verseker dat die woordsoekmetode sowel as die gebaarsoekmetode (in aansluiting met die tematiese soekmetode) suksesvol is en die toepaslike resultate lewer.

\section{Erkenning}

In figure 9, 10 en 13 is al die lynsketse van gebare die eiendom van die Online Dictionary of New Zealand Sign Language (http://nzsl.vuw.ac.nz/).

\section{Bronnelys}

Bosman, D.B. et al. (Reds.). 19848. Tweetalige Woordeboek/Bilingual Dictionary. Kaapstad: Tafelberg. Brien, D. (Red.). 1992. Dictionary of British Sign Language/English. Londen: Faber\&Faber.

Dagut, M. 1981. Semantic Voids as a Problem in the Translation Process. Poetics Today 2(4): 61-71.

Du Plessis, M. 1993. Tweetalige Aanleerderswoordeboek/Bilingual Learner's Dictionary. Kaapstad: Tafelberg.

Fourie, H. 2013. 'n Leksikografiese model vir 'n elektroniese tweetalige grondslagfasewoordeboek van SuidAfrikaanse Gebaretaal en Afrikaans. Ongepubliseerde D.Litt.-proefskrif. Stellenbosch: Universiteit Stellenbosch.

Gouws, R.H. en D.J. Prinsloo. 2005. Principles and Practice of South African Lexicography. Stellenbosch: SUN PReSS.

Gouws, R.H., L. Potgieter en S. Burgess (Reds.). 2010. Longman Grondslagfasewoordeboek Afrikaans/ Engels. Kaapstad: Maskew Miller Longman. 
Howard, S. 2008. Finger Talk: South African Sign Language (SASL) Dictionary. Gillitts: Fulton School for the Deaf.

Kritzinger, M.S.B., P.C. Schoonees en U.J. Cronjé (Reds.). 1972 ${ }^{11}$. Groot Woordeboek AfrikaansEngels / Major Dictionary English-Afrikaans.Pretoria: J.L. van Schaik.

Manley, J., J. Jacobsen en V.H. Pedersen. 1988. Telling Lies Efficiently: Terminology and the Microstructure in the Bilingual Dictionary. Hyldgaard-Jensen, K. en A. Zettersten (Reds.). 1988. Symposium on Lexicography III. Proceedings of the Third International Symposium on Lexicography, May 14-16, 1986, at the University of Copenhagen: 281-302. Tübingen: Max Niemeyer.

McKee, R. en D. McKee. 2012. New Zealand Sign Language Online: Insights from the Making of a Modern, Multimedia Dictionary. Programrede aangebied tydens die 17de jaarlikse Internasionale Afrilex-konferensie van 2 tot 5 Julie 2012 by die Universiteit van Pretoria, Pretoria, SuidAfrika.

Rowlinson, W. 20012. Oxford French Dictionary and Grammar. Oxford/New York: Oxford University Press.

Svensén, B. 2009. A Handbook of Lexicography: The Theory and Practice of Dictionary-Making. Cambridge: Cambridge University Press.

Wikipedia. 2012. Glossing Signed Languages. http://en.wikipedia.org/wiki/Gloss\#Glossing_signed_ languages op 1 Junie 2012. 